\title{
WEST INDIAN CARABIDAE $X$. THREE MORE SPECIES FROM JAMAICA, INCLUDING A NEW CAVE COLPODES*
}

\author{
By P. J. Darlington, Jr. \\ Museum of Comparative Zoology, Harvard University
}

The following three species are additions to the list of Jamaican Carabidae recorded in my earlier papers (Psyche Vol. 48, r94I, pp. IO-I5; and Occasional Papers of the Museum of the Institute of Jamaica No. 8, 1953).

\section{Colpodes cavicola n. sp.}

Form of a slender Agonum (Platynus), but with long head and long, slender appendages; brownish piceous, margins of prothorax and elytra not paler, legs brownish piceous, antennae and palpi paler brown; moderately shining, elytra not much duller than head and prothorax; upper surface almost impunctate, with microsculpture lightly impressed, isodiametric on front of head, transverse on pronotum and elytra. Head rather elongate, .84 and .83 width prothorax (in $\delta^{\top}+9$ measured); eyes rather large, moderately prominent; genae slightly shorter than eyes, oblique, not swollen; neck constriction indistinct; front convex, with normal, parallel impressions anteriorly; posterior supraocular setae present, between posterior edges of eyes; anterior supraocular setae absent; antennae long and slender but otherwise normal; mentum with an acute tooth. Prothorax subquadrate; about as long as wide (but appearing longer), width/length I.02 and r.02 (in $0^{7}+$ measured); base about I/ro wider than apex; apex slightly, broadly emarginate; base almost truncate; sides broadly, irregularly arcuate especially near middle of length, nearly straight and converging anteriorly, and nearly straight, converging, and usually slightly and broadly sinuate posteriorly; posterior angles narrowly rounded; lateral margins moderate, slightly wider posteriorly; both pairs lateral setigerous punctures lacking; disc normal and normally impressed; basal marginal line entire, apical one interrupted at middle. Elytra about $2 \times$ wide as prothorax, long, almost subparallel; humeri prominent but broadly rounded, with basal margin entire and scarcely angulate at humeri; sides almost straight and slightly diverging to about middle of length, then arcuate to weak subapical sinuations; apices bluntly angulate or narrowly rounded about

\footnotetext{
*Manuscript received by the editor April 3, 1964.
} 
opposite ends of 2nd striae; striae rather lightly impressed, vaguely punctulate; internals flat or slightly convex, 3rd normally 3-punctate. Inner wings fully developed; metepisterna long. Body below with fine punctures on sides of mesosternum, otherwise impunctate; abdomen not pubescent. Tibiae not grooved on outer edges; hind tarsi slender, basal segments grooved above on outer side, less so on inner side; 4th hind-tarsal segment with very long outer lobe and much shorter inner one; 5th hind-tarsal segment without accessory setae. External sexual characters normal. Length 9.5-1 I.0; width 3.2-3.7 mm.

Holotype $\sigma^{7}$ (M. C. Z. Type No. 29,463) and 6 paratypes ( 2 in M. C. Z., 4 in Museum of the Institute of Jamaica) all from St. Clair Cave, St. Catherine, Jamaica, 5 March 1954, collected by C. B. Lewis and R. P. Bengry.

This is a distinct, well defined species. It differs from all previously known Jamaican Colpodes in lacking both pairs of lateral prothoracic setae, and it has a unique combination of other specific characters. It is perhaps a distinct member of the Jamaican vagepunctatus-macersubovalis group, beginning to be specialized for life in caves. However, the specialization has not yet gone far. The brownish rather than black color and the long, slender appendages may be adaptations to life in caves; but the eyes are not much reduced and the wings are still fully developed. Another, somewhat similar (but probably not related) agonine, more highly modified for life in caves, is Speokokosia corneti Alluaud of the Grotte de Kokosi in the Congo in tropical Africa. In Speokokosia the eyes are much reduced, the wings have atrophied, and more depigmentation has occurred. In time, the Jamaican Colpodes may be expected to evolve in this direction.

\section{Callida caymanensis Darl.}

Entomologist's Monthly Magazine, 83, 1947, 210.

One specimen is before me from Crossroads, St. Andrew, Jamaica, 24 Nov. 1954, T. H. Farr. This is the first Jamaican record for the species - but when I described it, from the Cayman Islands, I suggested that it might prove to be Jamaican.

\section{Pentagonica vittula Darl.}

Memorias de la Sociedad Cubana de Historia Natural, 13, 1939, 100.

Three specimens now before me constitute the first records of this species from Jamaica. It was previously known only from Hispaniola. Two of the specimens are from Upper Mt. View, St. Andrew, Jamaica, 19 Nov. 1954, C. B. Lewis; and the other is from Beverly Hills, St. Andrew, 23 Dec. 1954, R. P. Bengry. 

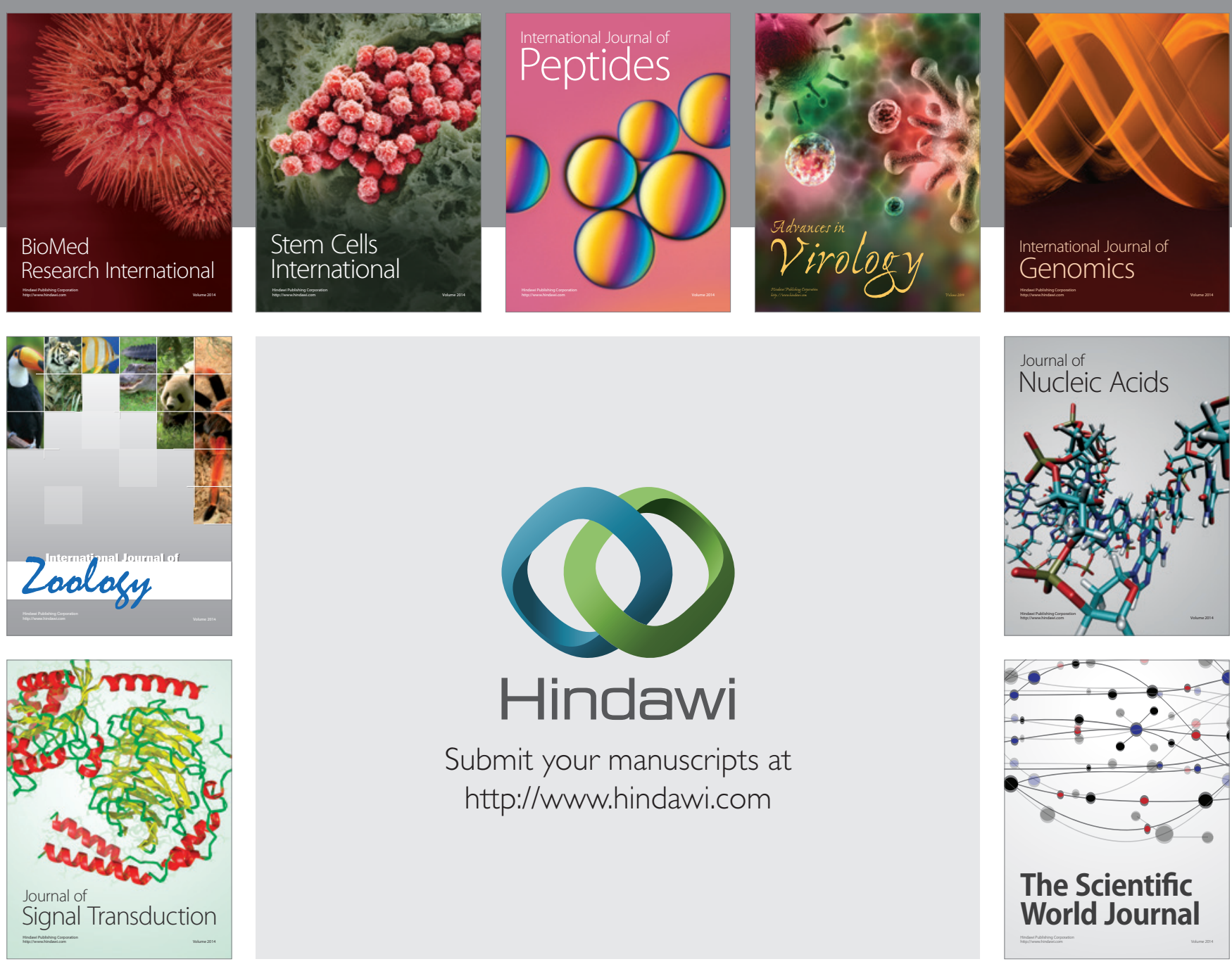

Submit your manuscripts at

http://www.hindawi.com
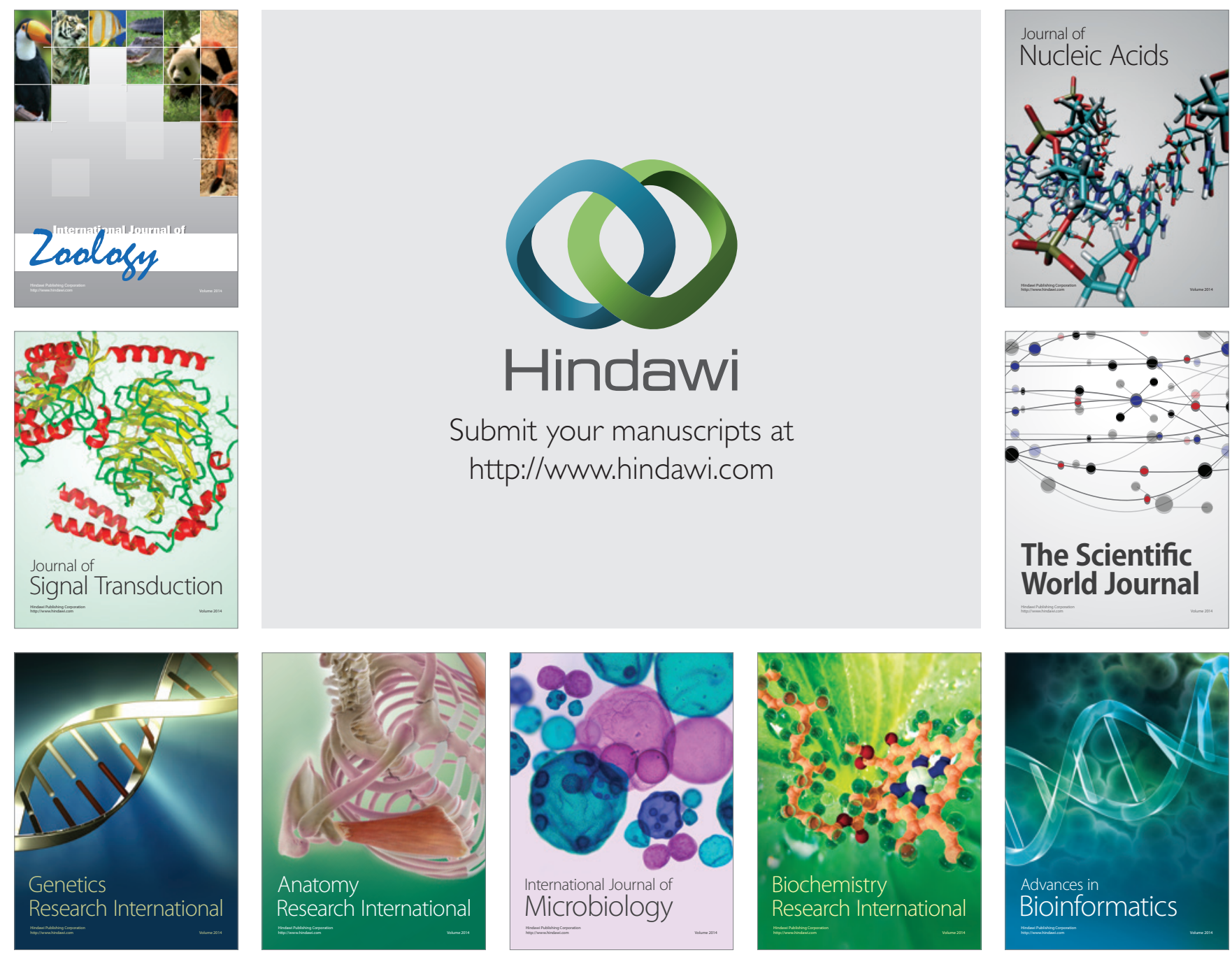

The Scientific World Journal
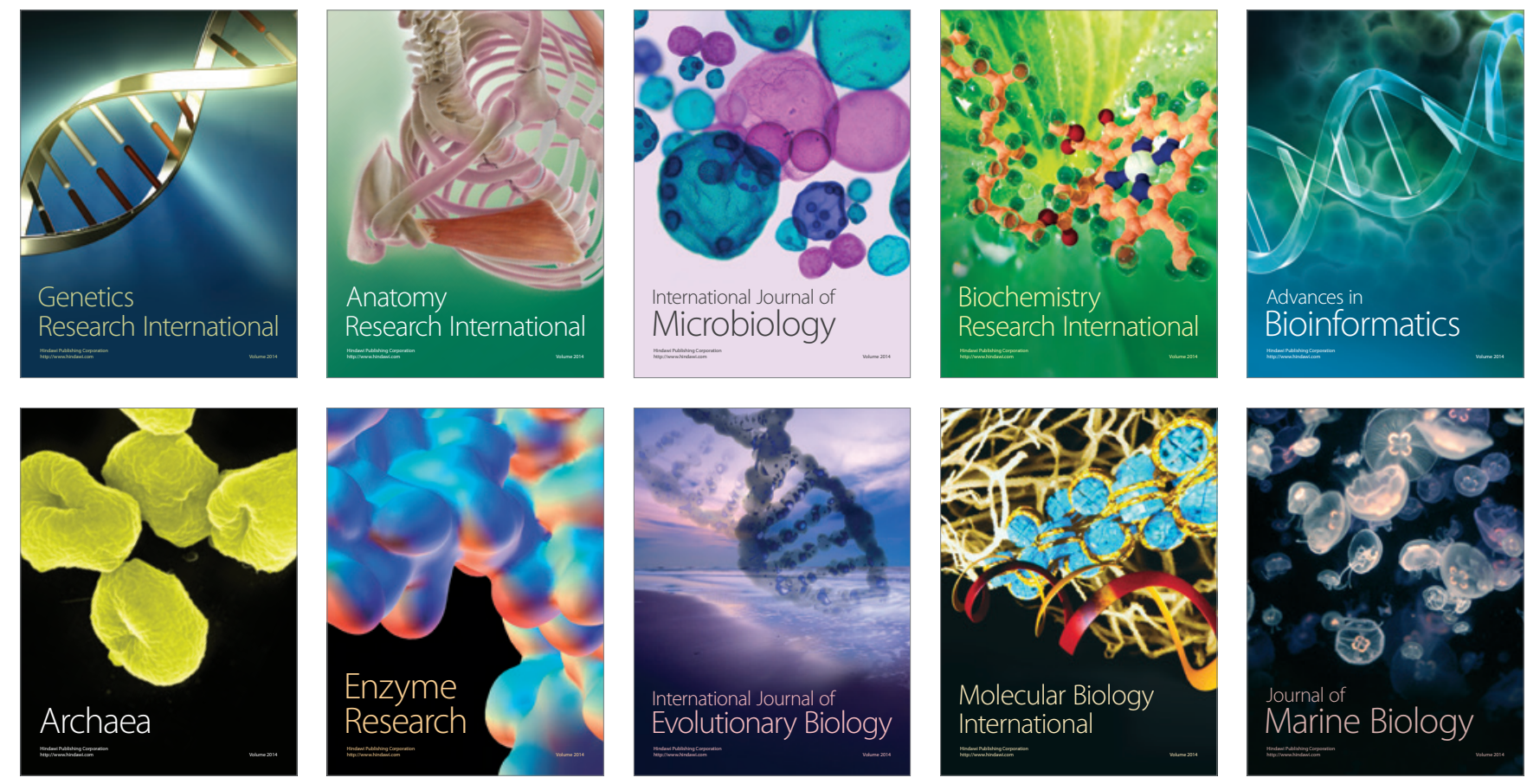